\title{
'n Pneumatologiese benadering tot die teologie
}

\author{
S J P Brand ${ }^{1}$ \\ (Universiteit van Pretoria)
}

\section{ABSTRACT}

\section{A pneumatological approach towards theology}

This article investigates the relationship between the subjective experiential side of faith and the objective rational side thereof. The two Theologians, Karl Rahner and John Calvin both propose, from different perspectives, a unity between rationality and experience. A Pneumatological approach emphasizes a theology of accountability and responsibility (teologie van verantwoording). This theology acknowledges the importance of man's experience and man's search for purpose and meaning. Furthermore, from a Scriptural point of view, God places man in various relational contexts. God expects responsibility/accountability towards Him, towards one's fellow man and the whole of creation. Man's response is initiated in prayer guided by the Holy Spirit. In fulfilment of his/her personal responsibility/accountability a sense of meaning and purpose is achieved.

\section{INLEIDING}

Geloof het altyd 'n objektiewe en 'n subjektiewe kant, ons sou ook kon sê ' $n$ rasionele en ervaringsmatige $\mathrm{kant}^{2}$. Soms lê die teologie meer klem op die een ten koste van die ander; ek kan so vasval in my eie subjektiewe geloofservaringe dat ek God nie meer raaksien en dit wat Hy gedoen het en nog steeds elke dag doen sonder enige

1 Hierdie artikel is gebaseer op navorsing wat gedoen is vir ' $n$ DD graad in die Departement Dogmatiek en Christelike Etiek van die Fakulteit Teologie aan die Universiteit van Pretoria. Die titel van die proefskrif is: 'Logika van die geloof: Gebed as die raakpunt tussen rasionaliteit en ervaring by Rahner en Calvyn. Die promotor was: prof. dr. C J Wethmar.

2 Die artikel gaan uit van die veronderstelling dat daar ' $n$ subjektiewe ervaringsmatige kant van die werklikheid asook ' $n$ objektiewe of rasionele 'meer as' kant is. Die mens is wesenlik 'n wese wat aangespreek word. Die twee teoloë waarby ons gaan stil staan is Karl Rahner en Johannes Calvyn. Beide werk beide met hierdie veronderstellings. Rahner poog om hierdie voorveronderstelling met behulp van ' $n$ kennislerige metode uit te werk. Calvyn benader die objektiewe en subjektiewe kant vanuit die Skrif openbaring. 
toedoen van my kant af $\mathrm{f}^{3}$. Die objektiewe kant van die geloof kan ook oorbeklemtoon word ten koste van die subjektiewe geloof ${ }^{4}$. Teologie

3 Die subjektiewe kant van die geloof het seker soos nog nooit na vore gekom in teologiese bewegings soos o.a die charismatiese beweging. Hierdie bewegings is niks nuut nie. Dit vind reeds in die 18de eeu uiting in die bloeiende Piëtisme. Smit is van mening: "Ook in die piëtistiese gedaante gaan dit om die moderne mens wat homself ontdek het en ernstig opneem as laaste perspektief en finale waarheidskriterium...[N]ie die eenmalige heilshandelinge is van belang nie maar die vraag of Christus in die hart van die gelowige gebore is. Die innerlike vroomheidsbelewing word gemaak tot die bron en waarborg van die waarheid en sodoende word die geloof veilig gestel in 'n mistieke ruimte van die 'allerindividualistiese' ervaring” (Smit, D J 1979. Teologie as Antropologie?, ' $n$ kritiese beoordeling van die transendentaal-antropologiese teologie van Karl Rahner, ongepubliseerde proefskrif, Univ van Stellenbosch). Barth (1972:114-115) se beoordeling: "In its basic form, in so to speak the original Pietist, it is individualism. The real birth of Christ is in our hearts; his real saving death is that which we see accomplished in ourselves, that which we have to accomplish ourselves; his real resurrection is his triumph in us as those who believe in him. Accordingly, original Pietism can be and often was a revival of much earlier historical mysticism" Barth wys ook daarop dat die sg. 'woordelikse inspirasieleer' van die ortodoksie ook hier tuis hoort (Barth, K 1972. Protestant theology in the nineteenth century, London: SCM, 114-115). 'n Beweging soos die sg. 'nuwe reformasie' met die bevraagteken van die Skrif en die dogma van die kerk sou ook onder die subjektiewe kant tuisgebring kan word; die vraag wat hier gevra word is hoe 'objektief' is die objektiewe dogmas van die kerk; is alle waarheid nie uiteindelik subjektief gekleur nie. Barth sowel as Tillich is van mening dat die teologiese stryd in die 18de eeu ' $n$ stryd was tussen 'n naturalistiese teologie en rasionalistiese teologie aan die een kant teenoor ' $n$ bonatuurlike teologie. Die belangrike punt word gemaak: in hierdie stryd was die piëtisme en rasionalisme aan dieselfde kant want albei neem hulle uitgangspunt vanuit die subjek. Die gemeenskaplikheid in beide gevalle is die mistiek. Volgens Tillich is dit een van die mees belangrike insigte ten einde die ontwikkeling van die Protestantisme sedert die Reformasie te verstaan (Tillich, P 1967. Perspectives on 19th and 20th Century Protestant Theology, London, 19). Die winspunt van hierdie bewegings is dat ons aandag opnuut gevestig word op die subjektiewe kant van geloof.

4 Ons sien hierdie oorbeklemtoning veral in die gereformeerde ortodoksie. "Die skoolse regsinnigheid het met sy krampagtige besorgdheid om die suiwer leer al hoe meer vervreemd geraak van die religieuse lewe in die kerk, juis omdat dit geen voedsel kon bied vir die konkrete geloofslewe van elke dag nie. ' $n$ Onheilsame kloof is geslaan tussen leer en lewe, tussen geloofsteorie en geloofspraktyk, "n kloof wat al hoe dieper geraak het namate die ortodoksie meer en meer " $\mathrm{n}$ doel in sigself geword het" (Rossouw, H W 1963. Klaarheid en interpretasie, Enkele probleemhistoriese gesigspunte in verband met die leer 
of geloof wat net bestaan uit 'n klomp geloofswaarhede wat die mens nie self ervaar of deel van sy leefwêreld en ervaring kan maak nie, is dood (König 2002:165; McGrath 1994:192) ${ }^{5}$. Die vraag waarmee hierdie artikel hom besig hou is van meer as net akademiese belang; dit sluit aan by die ervaring van ' $n$ diep skeiding en breuk en verwarring wat ons moderne lewe en denke kenmerk (Sheldrake 1998:3v) ${ }^{6}$.

Gebed wys vir ons op ' $n$ eenheid tussen die objektiewe en subjektiewe kante van die geloof (Ebeling 1979:209) . Häring

van die duidelikheid van die Skrif. Proefskrif. Amsterdam: Jacob van Kampen, $350)$.

$5 \quad$ König stel die volgende voor: "As openbaring deur ervaring gekom het, is ervaring ook vandag nog wesenlik in ons godsdiens...[D]it kan beteken dat spiritualiteit belangriker as leer is, en dat bepaalde stromings in die vernuwingsbeweging wat nie leersuiwerheid insluit onder die onontbeerlike eienskappe van 'n groeiende gemeente nie, dit reg het. Ons weet uit die praktyk dat kerke wat die vinnigste groei nie daardie met die suiwerste leer is nie, maar eerder die kerke met die hartlikste gesindheid en die spiritualiteit wat mense die meeste inspireer" (König, A 2002, Ek glo die Bybel - ondanks al die vrae. Lux Verbi.BM, Wellington). McGrath maak die stelling: "To fail to ground the gospel in the individual world of experiences is to risk compromising the future of the church itself" (Mc Grath, A E 1994. Spirituality In An Age Of Change Rediscovering the Spirit of the Reformers, Zondervan: Grand Rapids, 192).

6 Die stelling kan gemaak word dat intellektuele aannames sedert die Verligting ook sy invloed in die teologie gehad het. Daar het ' $n$ soort leerstellige vakuum binne en buite die kerk ontstaan waarvolgens ou gevestigde waarhede nie sonder meer aanvaar word nie. Sommige teoretici meen dat dit nie meer moontlik is om met ' $n$ koherente geloofsisteem na vandag se mens te kom nie. Spiritualiteit het ' $\mathrm{n}$ privaat aangeleentheid geword (Sheldrake, P 1998. Spirituality and Theology. Christian Living and the doctrine of God. Darton, Longman \& Todd: London, $3 \mathrm{v}$ ).

7 "In der traditionellen Gestalt der Dogmatik stellt die lehre von Gebet denjenigen Punkt dar, in dem die christliche Glaubenslehre einerseits mit dem Weltwirklichkeit im Ganzen, anderseits mit allen Weisen des Gottesverständnisses verknüpft ist." (Ebeling 1979:209) Rahner sowel as Calvyn wys ons op die belang van gebed vir die teologie. In gebed vind beide " $n$ raakpunt tussen rasionaliteit en ervaring; dit wat juis in ons moderne tyd geskei geraak het. Hierin word aansluiting gevind by 'n baie ou Christelike spreuk: "lex credendi lex orandi' of te wel soos dit oorspronklik geformuleer is "legem credendi lex statuat supplicandi" (Wethmar, C J 1988, 'Godsleer en gebed' in die bundel 'n Woord op sy tyd, red. Wethmar, C J en Vos, C J A 1988, NG 
(1975:1) maak die volgende stelling: "Our life is authentically Christian to the extent that we know Christ and listen to his word with a readiness to respond with our whole being. Christan life needs prayer: the integration of faith and life".

My voorstel is dat aandag geskenk word aan ' $n$ pneumatologiese benadering tot die teologie. Die skakelwerk tussen die objektiewe en subjektiewe kant van die geloof word gedoen onder leiding van die Heilige Gees ${ }^{8}$.

\section{RAHNER SE VOORSTEL}

In ' $n$ sekere sin wys Rahner se voorstel vir ons die weg na ' $n$ pneumatologiese benadering. Soos min ander teoloë vestig Rahner ons aandag op die subjektiewe kant van die geloof. Volgens Rahner is daar sekere gewoon menslike ervarings wat ons wys op ' $n$ heelheid en eenheid wat ons in ons moderne lewe en denke verloor het. Rahner se teologie sou ook as " $n$ antropologiese of transendentale teologie beskryf kon word (Kasper 1988:246v) ${ }^{9}$. Ons

kerkboekhandel, 217 v) vir die Latynse spreuk word verwys na Migne, J P (ed), Patrologia Latina, 51, 205-212.

8 Rahner se voorstel sou as ' $\mathrm{n}$ Antropologiese benadering beskryf kon word. Die klem val op die mens as vraag. Daarteenoor sou mens sekerlik van ' $n$ Christologiese benadering kon praat. Die klem soos in Barth se geval val meer op die goddelike antwoord. Ek kies vir ' $n$ pneumatologiese benadering omdat dit ruimte laat vir die antropologiese sonder om die teologiese te kort te doen.

9 Ons sou hierdie wending in die teologie alreeds kon terugvoer na Duns Scotus wat die vraag stel 'Quod sit praxis?' waardeur hy die teologie eensydig as praktiese wetenskap bestem. Die geloofsleer sou al hoe meer in die toekoms eensydig in sy relevansie vir die mens uiteengesit word. Kasper verwys na Duns Scotus, In Sent., prol. p.4 q.2 ad 1 (Kasper 1988). "Die Wissenschaftspraxis der Theologie, in Handbuch der Fundamental-Theologie, 4. hg Walter Kern ea. Freiburg: Herder, 246 v. "Rahner vollzieht eine kopernikanische Wende, er treibt Theologie vom Menschen her und aus Menschen hin.' So maak Rahner erns met grondliggende insigte uit die filosofie sedert Kant, Fichte, Hegel en Heidegger nl. 'da $\beta$ wir alle Wahrheit, auch alle Glaubenswahrheit nicht anders besitzen denn als von uns erkannte, angeeignete und interpretierte Wahrheit. Auch Gottes Wort fällt nicht unvermittelt, sozusagen senkrecht vom Himmel; wir haben es nur "in, mit und unter" uns gehörtem, verstandenem, geglaubten und bezeugtem Wort von Menschen...[W]issenschaftstheoretisch formuliert: $\mathrm{Er}$ hat einem Paradigmawechsel vollzogen und eine epochal neue Gestalt von Theologie inauguriert" (Kasper 1988:266, 267). 
sou sy teologie ook as ' $n$ biografie van sy eie ervaring met God kon beskryf. Tradisioneel word onderskeid getref tussen teologieswetenskaplik spreke oor God en biddende spreke tot God. Hierdie sake kan volgens Rahner nie geskei word sonder dat albei skade ly nie (Rahner 1982b:224). Daarom staan hy krities teenoor enige skeiding tussen die geestelike en alledaagse (Klinger 1994:21) ${ }^{10}$. Vandaar maak hy nie ' $n$ skeiding tussen sy geestelike en sy meer teologiese werke nie. Eintlik gaan dit om ' $n$ direkte ervaring wat elke mens met God en sy genade mag hê; hierdie ervaring stel Rahner dan ook gelyk aan gebed (Rahner 1979:350) ${ }^{11}$. Dis die ervaring waarvoor God die mens geskep het; hierdie ervaring kan verskillend beskryf word; dit kan beskryf word as die ervaring van God se liefde; die ervaring van die genade; die ervaring van die Heilige Gees; watter begrippe ons gebruik is nie belangrik nie; die ervaring is waaroor dit eintlik gaan; vandaar Rahner se bekende stelling: 'The Christian of the future will be a mystic or he or she will not exist at all.' Uit die onmiddellike konteks waarin die stelling voorkom blyk Rahner se bedoeling duideliker:

"If by mysticism we mean, not singular parapsychological phemomena, but a genuine experience of God emerging from the heart of our existence, this statement is very true and its truth and importance will become still clearer in the spirituality of the future ... [P] ossesion of the Spirit is not something of which we are made factually aware merely by pedagogic indoctrination as a

10 "Die Abspaltung des Erhabenen vom Alltäglichen, der Hoheit von Niedrigkeit hei $\beta t$ in der Theologie Extrinszismus. Er meint eine wechselseitige Entfremdung von Natur und Gnade, von Körper und Geist, von Gott und Welt, von Kirche und Gesellschaft. Er steht für ein gespaltenes Leben und Denken" (Klinger, E 1994. Das Absolute Geheimnis im Alltag entdecken: Zur spirituellen Theologie Karl Rahners, Würzburg: Echter Verlag, 21).

11 Rahner beskryf gebed as 'grundakt' van menswees. Die term Grundakt verwys na sekere dade van menswees waarin die heelheid en eenheid van menswees te vinde is; dis ook dade wat enige nadenke voorafgaan, met ander woorde dade waarin rasionaliteit en ervaring nie geskei kan word nie. "Es gibt Wirklichkeiten im menschlichen Leben, die weil sie dass eine Ganze des Menschen betreffen und aktualisieren, nicht von einem Punkt außerhalb ihre aufgebaut und verstanden werden können" (Rahner, K 1979. "Beten als Grundakt' in Rechenschaft des Glaubens, hg. von Lehman, K und Raffelt, A. Freiburg: Herder, 350). 
reality beyond our existential awareness, but is experienced inwardly... [T] he solitary Christian makes the experience of God and his liberating grace in silent prayer, in the final decision of conscience, unrewarded by anyone, in the unlimited hope which no longer cling to any particular calculable assurance, in the radical disappointment of life and in the powerlessness of death" (Egan 1980:139v.; Rahner 1983a:18v.) ${ }^{12}$.

Dis die ervaring wat Rahner vind in die geestelike oefeninge van Ignatius van Loyola; Ons verwys na Rahner se woorde in sy geestelike testament na aanleiding van Ignatius:

"Ich habe Gott erfahren, den Namenlosen und Unergründlichen, Schweigenden und doch nahen, in der Dreifaltigkeit seiner Zuwendung zu mir. Ich habe Gott erfahren auch und vor allem jenseits aller bildhaften Imagination. Ihn, der, wenn er so von sich aus in Gnade nahekommt, gar nicht mit etwas anderem verwechselt werden kann" (Rahner 1983b:374).

Die bedoeling van die teologie is om elke mens te lei om hierdie ervaring te beleef; selfs kerklike dogmas is alleen hulpmiddels en moet daarom ook in ' $n$ moderne en postmoderne tyd so verstaan en interpreteer word dat vandag se mens ook ' $n$ ervaring met God en sy genade kan hê. Dit sluit in ervarings van liefde, persoonlike verantwoordelikheid, die ervaring van die dood of eensaamheid. Hierin ervaar die mens dat sy lewe aan die onbegryplike misterie grens. Reeds in hierdie transendentale ervaring is daar volgens Rahner ' $n$ 'nie-tematiese' kennis van God aanwesig. Hy stel dit as volg:

"Nichts wei $\beta$ der Mensch in der letzten Tiefe genauer, als da $\beta$ sein wissen, d.h. das, was man im Alltag so nennt, nur eine kleine Insel in einem unendlichen Ozean des Undurchfahrenen ist, eine schwimmende Insel, die uns

12 Egan, H 1980. 'The Devout Christian of the future will... be a mystic': Mysticism and Karl Rahner's theology, in: Theology and discovery: Essays in honour of Karl Rahner, ed. W J Kelly. Milwaukee: Marquette Univ Press, 13958. Sien ook sy artikel 'The spirituality of the future' in Rahner, 1983a. The practice of faith: a Handbook of contemporary spirituality, New York: Crossroad, 18-28. 
vertrauter sein mag als dieser Ozean, aber im Letzten getragen und nur so tragend ist, so da $\beta$ die existenzielle Frage an den Erkennenden die ist, ob er die kleine Insel seines so genannten Wissens oder das Meer des unendlichen Geheimnisses mehr liebe; ob ihm das kleine Licht, mit dem er diese Insel ableuchtet - man nennt es Wissenschaft -, ein ewiges Licht sein soll, das ihm (das wäre die Hölle) ewig leuchtet ... [U]nd nur dort, wo man sich der Frage nach dem Fragen, dem Denken des Denkens, dem Raum der Erkenntnis und nicht nur dem in dieser Transzendenz kategorial raumzeitlich Erfaßten zuwendet, ist man eben am Beginn, ein Homo religiosus zu werden" (Rahner 1976:33-34).

Rahner maak gebruik van sy transendentaal antropologiese metode om die dogmas en leerstukke van die kerk te herinterpreteer sodat dit sin maak; dat dit, belangriker nog, die mens tot ' $n$ eie ervaring en geloofskeuse kan bring. Rahner meen die voortbestaan van die Christelike geloof is afhanklik van hierdie ervaring ${ }^{13}$. Hierdie benadering van Rahner met die klem wat gelê word op ' $n$ indiwidu se eie ervaring van genade sluit aan by die moderne mens se soeke na sin; dis juis hier waar Rahner meen dat geloof ' $n$ bydrae kan lewer. Die mens is wesenlik geskep as ' $n$ mens wat vra na die sin van die lewe.

Hierdie mens op soek na sin is tegelyk ' $n$ moderne of postmoderne mens. Dit is die mens wat sy vryheid ontdek het; slegs deur sy eie denke kan hy sin aan sy lewe gee. Hierdie ontwikkelinge sedert Descartes en veral Kant kan volgens Rahner nie geïgnoreer

13 Wanneer Rahner by die Christelike geloofswaarhede kom, stel hy ' $\mathrm{n}$ subjektiewe rangorde van waarhede voor, naas die gebruiklike objektiewe rangorde. Die Christelike boodskap moet oorgedra word op ' $n$ wyse dat die nie voorkom as 'n klomp mites van 'n verbygaande era nie (Rahner 1983d). 'Hierarchie der Wahrheiten', in Schriften zur Theologie XV. Einsiedeln: Benziger Verlag, 168). Rahner beoog hiermee geen subjektiewe reduksie van geloofswaarhede nie. Wel van belang is dat net antwoorde op werklike vrae van die mens hom interesseer. Seckler wys op die sentrale bedoeling van Rahner met sy Grundkurs naamlik "Das Ganze von seiner Wurzelhaften Einheit her erstmals ergreifen" (Seckler, M 1984. Das eine Ganze und die Theologie, in: Glaube in Prozess, hg. Klinger, E und Wittstadt, K Herder: Freiburg, 830). 
word nie (Kasper 1979:267) ${ }^{14}$. Vandaar het die moderne mens ' $\mathrm{n}$ groot probleem met die aanvaarding van enige vreemde outoriteite; veral die vader beeld van God en die feit dat God ' $n$ persoon is waarteenoor die mens verantwoordelik is, het ' $\mathrm{n}$ groot probleem geword. Rahner sluit nie net aan by die moderne denke nie maar lewer ook kritiek op die moderne rasionalistiese teologie van sy tyd, wat aanleiding gee tot ' $n$ skeiding tussen rasionaliteit en ervaring. Rahner se teologie vertoon sekerlik postmoderne trekke. Daar is ' $n$ dimensie van die werklikheid wat nie genoegsaam deur die natuurwetenskaplike metode verreken word nie; dis die werklikheid van die ervaring van menswees en die dimensie van die 'Geheimenis' wat onlosmaaklik daarmee saamgaan (Rahner 1967:112 ev $)^{15}$. Daarom stel Rahner voor dat ons eerder van God praat as die 'heilige Geheimenis'. God is nie ' $n$ blote objektiewe 'teenoor' soos die objekte van menslike kennis nie; God is deel van die geheim van menswees; God is te vind in die geheimenis kant van menswees; dis die kant wat ons as mense nodig het om ons menswees sinvol te beleef. "Der Begriff 'Gott' ist nicht ein Ergreifen Gottes, durch das der Mensch sich des Geheimnisses bemägtigt,

14 Rahner sluit aan by grondliggende insigte uit die filosofie sedert Kant en waardeer hierdie ontwikkelinge as wesenlik Christelik. Hy neem dit dan ook as sy vertrekpunt. Hierdie vertrekpunt behels dat alle waarheid, ook geloofswaarheid, alleen bestaan as menslik geïnterpreteerde waarheid. Kasper vat dit as volg saam: "da $\beta$ wir alle Wahrheit, auch alle Glaubenswahrheit nicht anders besitzen denn als von uns erkannte, angeeignete und interpretierte Wahrheit. Auch Gottes Wort fällt nicht unvermittelt, sozusagen senkrecht vom Himmel; wir haben es nur 'in, mit und unter' von uns gehörtem, verstandenem, geglaubten und bezeugtem Wort von Menschen. ... Wissenschaftstheoretisch formuliert: Er hat einem Paradigmawechsel vollzogen und eine epochal neue Gestalt von Theologie inauguriert" (Kasper, W 1979. Theologie in einer Zeit des Umbruchs in: Theologische Quartalschrift, 159, München: Erich Wewel Verlag, 267).

15 In ' $n$ artikel wat handel oor die sinvraag, bevraagteken Rahner die moderne kennisideaal. Die ideaal wat juis daarin geleë is dat die mens deur middel van sy rede wil heers en beheers. Volgens hierdie kennisideaal staan sin en geheimenis radikaal teenoor mekaar. Rahner konfronteer hierdie ideaal met die sentrale Christelike begrip, van die onbegryplikheid van God. Vanuit die gedagte van die onbegryplikheid van God blyk dit dat kennis meer is as om te beheer en in beheer te wil wees. Kennis is ook om 'gegryp' te wees deur die objek van kennis; deur die geheimenis agter alle kennis (Rahner, K 1967. Glaubst du an Gott? München: Verlag Ars Sacra, 112-127). 
sondern ein Sich-ergreifen-Laßen von einem anwesenden und sich immer entziehenden Geheimnis. Dieses Geheimnis bleibt Geheimnis, auch wenn es sich dem Menschen eröffnet und so allererst den Menschen als Subjekt dauernd begründet" (Rahner 1976:63). Die vraag is natuurlik of Rahner nog daarin slaag om God sy Godheid te laat behou? ${ }^{16}$

Ons sou gebed op hierdie punt as ' $n$ toets vir die teologie beide na sy subjektiewe kant as na sy objektiewe kant kon sien. Aan ' $n$ teologie wat vanuit ' $\mathrm{n}$ subjektiewe of antropologiese vertrekpunt beoefen word, vra gebed die vraag na die objektiewe aangesproke karakter waarvoor die teologie en die geloof die antwoord is (Schlink 1961:25) ${ }^{17}$. Die gevaar is dat ' $n$ gebed vanuit ' $n$ antropologiese benadering blote selfgesprek word; dat geloof eindig in die mistiek ${ }^{18}$.

Tog moet onsself afvra: sluit ' $n$ pneumatologiese benadering al hierdie al te menslike besig wees, soeke en vrae van die mens uit? Calvyn wei ' $n$ hele hoofstuk aan die Godskennis waaraan die Heilige Gees die mens van nature deel gegee het (Calvyn 1984/1991:121 en $117)^{19}$.

16 Die feit dat Rahner se teologie voortspruit uit sy 'ervaring' met God, mag aanleiding gee tot ' $n$ siening dat sy teologie op een of ander private openbaring berus; ' $n$ teologiese konsep wat uit ' $n$ 'gebedservaring' spruit, maak dit nie immuun teen kritiek nie, veral as dit gaan om die waarheid van die Christelike geloof.

17 Die Lutherse dogmatikus E Schlink stel onder die opskrif die "Grundformen der theologischen Aussage', die gebed as die eerste. 'Das Gebet ist die Antwort auf das Evangelium in der Anrede des Göttlichen Du. In dieser Antwort wird die Heilstat, die durch das Evangelium verkündigt wird und geschieht, vom Glaubenden als ihm geschehen und als für ihm in Kraft stehend ergriffen und in Anspruch genommen" (Schlink, E 1961. Der kommende Christus und die kirchliche Traditionen. Göttingen: Vandenhoeck \& Ruprecht, 25).

18 Rahner praat van ' $n$ 'reductio in Mysterium'. Sien Rahner se derde artikel oor 'Reflections on Methodology in Theology' (Rahner 1974b:101-114).

19 "Ons stel dit as 'n onteenseglike feit dat daar ' $n$ bepaalde bewussyn van die godheid in die mens se verstand aanwesig is, ..." (Calvyn, J 1984/1991. Institusie van die Christelike godsdiens, vert Simpson, H W. I. 3. 1. Potchefstroom: CJBF, 121). Hierna afgekort as Inst. "Omdat die Here Hom dus in die eerste plek in die skepping van die wêreld sowel as in die algemene leer van die Skrif eenvoudig as Skepper openbaar en daarop as Verlosser in die 
"My opvatting in verband hiermee is dat Hy nie alleen hierdie wêreld wat Hy een maal geskep het, so met grenslose mag onderhou, met sy wysheid bestier, met sy goedertierenheid bewaar en in besonder die mensdom met sy geregtigheid en gerig regeer, uit barmhartigheid ophef en met sy bystand beskerm nie, maar ook dat nêrens 'n druppel van wysheid, lig, geregtigheid, mag, regskapenheid of egte waarheid te vinde is wat nie uit Hom ontspring en waarvan Hy nie die oorsaak is nie" (Inst. I, 2, 2:118).

Ons sou kon sê Rahner se voorstel open ons oë vir die geheim van menswees. Die vraag wat die mens aan die teologie stel is die vraag na sin. Ons kennis van onsself rig ons altyd op die kennis van God. Die geheim van menswees rig ons op die geheim van die Woord wat mens geword het. Hierdie geheim as draende grond gaan al ons nadenke te bowe.

\section{CALVYN SE VOORSTEL}

Rahner dwing ons tot ' $\mathrm{n}$ eietydse geloofsverantwoording. Calvyn sluit aan by Rahner:

"Byna die volle eindtotaal van ons wysheid wat ons as die ware en grondige wysheid moet beskou, bestaan uit twee dele: kennis van God en kennis van onsself. Hoewel die twee aspekte met baie bande aan mekaar verbind is, is dit tog nie maklik om te onderskei watter een van die twee aan die ander voorafgaan en hom voortbring nie. Want in die eerste plek kan niemand homself aanskou sonder om dadelik sy sintuie tot die aanskouing van God, in wie hy lewe en beweeg, te wend nie. ... Verder staan dit vas dat die mens nooit tot suiwer kennis van homself kom nie, tensy hy eers die aangesig van God aanskou het en uit die aanskoue van God tot ' $n$ ondersoek van homself neerdaal" (Inst I, 1, 1 en 2:113-114).

gedaante van Christus, kom hieruit 'n tweeledige kennis aangaande Hom na vore" (op cit 117). 
Godskennis is vir Calvyn eweneens nie kennis ter wille van kennis nie, maar kennis wat die mens ten diepste raak (Locher 1964:16) ${ }^{20}$. Calvyn se teologiese werk is gerig op die bevordering van ware Godsvrug $^{21}$. Calvyn beklemtoon die gedagte van ' $n$ eenheid tussen die subjektiewe en objektiewe kant van die geloof. In Calvyn se teologie is spanninge nie vreemd nie. Die teoloog van die Heilige Gees en gebed en ervaring is ook die teoloog van die openbaring en die uitverkiesing. Vir Calvyn is daar geen spanning tussen die leerstuk van die openbaring en uitverkiesing en die leerstuk oor die Heilige Gees waar die mens se persoonlike betrokkenheid in gebed beklemtoon word nie ${ }^{22}$. Hierdie eenheid sien ons in die opskrif van Boek 3 van die Institusie. Boek 3 handel oor "De modo percipiendae Christi gratiae, et qui inde fructus nobis proveniant, et qui effectus consequantur", dit is: "Die manier waarop ons die genade van Christus ontvang, die voordeel wat dit vir ons inhou, en die resultaat daarvan". Die gevolgtrekking wat gemaak kan word is dat die 'cognitio' van boeke I en II nie bloot handel oor ' $n$ kennisname nie, maar deelname en betrokkenheid. Soos die opskrif van Institusie, boek III dit stel, gaan dit om ' $n$ eksistensiële betrokkenheid by die kennis van God (Sprenger 1960:94 v) ${ }^{23}$. Die gedagte van deelname

20 "Gotteserkenntnis und Selbsterkenntnis bedingen einander" Locher, G W 1964. Testimonium internum: Calvins lehre vom Heiligen Geist und das hermeneutische Problem. in Theologische studien, heft 81. Zürich: EVZ verlag, 16).

21 "His signet ring depicted a heart lying in an open hand. His motto' was: "My heart I offer as though slain in sacrifice to God"' (Barth, K 1955. The Theology of John Calvin. Michigan: W B Eerdmans, 117 n 50. (Barth verwys na Calvyn se brief aan Farel gedateer 10/24/1540).

22 Vir Calvyn is daar geen sprake van ' $\mathrm{n}$ ware geloof sonder vroomheid nie. Groot dele van die Institusie word gewy aan sake van praktiese vroomheid. Veral gebed neem ' $n$ belangrike plek in Calvyn se teologie in. Hierdie gees deurtrek sy kommentare, preke en briewe. Hierdie klimaat kry ons dan ook later by die Heidelbergse Kategismus.

23 'Niemals kann hier Gott einfach als 'Gegenstand' unserer Erkenntnis gedacht werden. Alles vollzieht sich in dem lebendigen Gegenüber- und Miteinander-Handeln von ich und Du bei Gott und Mensch". Eintlik geld die bekende inleidingsin van I, 1,1 oor God en selfkennis Calvyn se hele werk. In Institusie III word hierdie kennis baie eksistensieel. "Beachtet man dabei die von Calvin so stark betonte gegenseitige Bedingtheit von Gottes- und Selbererkenntnis, so wird hier schon sichtbar, da $\beta$ es ein abstraktes, blo $\beta$ theoretische Erkennen Gottes nicht gibt. Und doch zeigt schon jenes Reden von 
aan die heil word ook duidelik in die inleidingsgedeelte van die derde deel van boek III, wat van die mooiste dele van die Institusie is:

"Om dus die dinge wat Hy van sy Vader ontvang het, met ons te deel moes Hy ons eie word en in ons inwoon. Daarom word Hy enersyds ons Hoof en andersyds ook die Eersgeborene onder baie broers genoem. Op ons beurt word van ons gesê dat ons in Hom ingelyf word en dat ons ons met Hom beklee... Dit is tog deur die werking van die Gees dat ons Christus en al sy seëninge kan geniet" (Inst III, 1, 1:699-700).

Die Heilige Gees moet werk sodat Christus nie verniet sy kosbare bloed gestort het nie (Krusche 1957:12) ${ }^{24}$.

Ons kry by Calvyn ' $n$ ander aksent as by Rahner. Vir Calvyn gaan dit om meer as ' $\mathrm{n}$ filosofiese probleem van die skeiding tussen subjek en objek; dit gaan om die skeiding tussen God en mens. Om die breuk te heel is meer nodig as ' $n$ filosofies-teologiese metode. Rahner praat van ' $n$ samevatting van die geloof, " $n$ geloofsverandwoording vir ons tyd. Eintlik gaan dit vir hom oor die vraag hoe geloofservaring inpas in die geheel van ons denke. Calvyn se antwoord hierop is: ons kan wel ' $n$ uiteensetting van ons geloof gee, geloof kan egter nie ingepas word in die geheel van ons denke nie

den zwei Stücken unserer Weisheit, wie weltenweit Calvin von jedem mystischen Pantheismus entfernt ist. Der Mystiker wurde sagen, Selbsterkenntnis und Gotteserkenntnis wäre im tiefsten Grunde ein und dasselbe. Es gibt auch hier blo $\beta$ gedankliches Erfassen des Gottesbegriff quod sit Deus -, es geht um das Kennen Gottes, wie er ist - qualis sit ... [S]o ist dann verständlich, da $\beta$ es bei diesem lebendigen gegenüber des Menschen und den sich überall offenbarenden Gott gelt: ... [U]nd diese 'pietas' kann nun wiederum, wie wir gesehen haben, nicht kenngelernt werden, ohne da $\beta$ sie eine "Entscheidung" eine Lebenswende herbeiführen. Die vera pietas mu $\beta$ 'geschmeckt' werden" (Sprenger, P 1960. Das Rätsel um die Bekehrung Calvins. Neukircherer Verlag, 94v).

24 "Ohne den Heiligen Geist wäre Christus umsonst (frustra) als Mittler zu uns gekommen (IV 2 39); sein Blut wäre unwirksam (irrite) geflossen (IV 2 1); er böte sein Licht vergeblich (frustra) an (IV 6 4); die Evangeliumpredigt träfe vergeblich (frustra) unser Ohr ... die ganze Lehre vom Heil stünde umsonst (frustra) in der Schrift ... die Heilsverheißung würde und vergeblich (frustra) angeboten" (Krusche, W 1957. Das wirken des Heiligen Geistes nach Calvin. Göttingen: Vandenhoeck \& Ruprecht, 12). 
(Molnar 1985:228) ${ }^{25}$. Vir Calvyn gaan dit veral om verantwoording teenoor God. Dit gaan om 'n kennis van die onbegryplike logika van God se genade wat ons menslike logika, alhoewel nie uitskakel nie, by verre oortref. Die Reformasie was ' $n$ herontdekking van God se 'vreemde logika'26.

Vanuit die perspektief van die openbaring word die rolle omgeruil. Die Heilige Gees word die leermeester en die mens leerling. Hier kom ons natuurlike Godskennis nie by om God as ons Vader tot ons heil te ken nie ${ }^{27}$. Die Heilige Gees moet ons deur die middele wat Hy gebruik oortuig van die waarheid van die evangelie ${ }^{28}$. Hierdie insigte word duidelik in Luther se worsteling om

25 Molnar meen dat ons nooit die geloof met behulp van die rede of 'ervaring' kan verklaar nie. Ons kan alleen ' $n$ uiteensetting gee van die Een in wie ons glo. Dit beteken ' $n$ basiese keuse tussen die objek van die filosofie, die 'syn' in die algemeen; en teologiese nadenke, die drie-enige God wat enige filosofiese nadenke te bowe gaan. Hy meen Rahner poog om die vryheid van God se openbaring te probeer handhaaf, tog trek hy "n streep daardeur omdat hy nie bereid is om hierdie basiese keuse te maak nie (Molnar, P D 1985, Can we know God directly" Rahner's solution from experience, in Theological studies, 46, 228v).

26 "Want as ons in die middag ons oë op die grond rig of enigiets wat rondom ons sigbaar is aanskou, lyk dit vir ons asof ons met "n baie sterk en skerp gesigsvermoë toegerus is; maar wanneer ons in die son inkyk en met oopgesperde oë reguit daarna kyk, word ons gesigsterkte, wat op die grond besonder kragtig was, dadelik deur so 'n groot glans afgestomp en verwar. Die gevolg is dat ons gedwing word om te erken dat ons skerpsinnigheid by die aanskouing van aardse voorwerpe louter stompsinnigheid is wanneer dit die son aangaan. Dit is ook die geval wanneer ons oor ons geestelike seëninge nadink" (Inst. I. 1. 3:115).

27 "Ek ontken wel nie dat daar hier en daar verstandige en gepaste uitsprake oor God by die filosowe voorkom nie. Dit smaak egter altyd na duiselingwekkende verbeeldingsvlugte. Soos hierbo gesê is, het die Here wel aan hulle ' $n$ effense smaak van sy Godheid verleen sodat hulle nie hulle onkunde as dekmantel vir hulle goddeloosheid kan voorhou nie. Soms het Hy hulle gedwing om bepaalde uitsprake te maak sodat hulle self deur die erkenning daarvan oortuig kon word. Wat hulle waargeneem het, het hulle so waargeneem dat hulle hoegenaamd nie deur die waarneming daarvan op die waarheid gerig is nie, laat staan nog geraak is" (Inst. II. 2. 18:391-2).

28 "Ek merk dat my woorde niks bereik om die verstand van mense oor die dinge van God te onderwys nie, behalwe as die Here deur sy Gees aan die mens die verstand daarvoor gee" (Inst. II. 2. 20:393). Oral in Calvyn se geskrifte vind ons die begrip 'getuienis van die Heilige Gees'. Die begrip "testimonium 
vrede te vind voor die aangesig van ' $\mathrm{n}$ toornige God. Vandaar ervaar feitlik al die Reformatore die ontdekking van die genade van God as ' $n$ soort bekering. Dis duidelik dat die Reformasie te make gehad het met ' $n$ diep geestelike ervaring. Jonker (1985:292) maak die volgende opmerking: "...dat die reformasie gebore is uit "n diep geestelike ervaring en nie in die eerste plek ' $n$ teologiese beweging was nie, maar " $n$ nuwe vorm van spiritualiteit wat homself verstaan het as "n suiwerder vorm van lewe voor die aangesig van God." Die probleem is ons praat miskien te maklik oor God en te min met God; ons besef nie die onoorbrugbare kloof tussen God en mens nie. As ons voor hierdie grens staan, is al wat oorbly gebed; en is die inhoud van ons gebed God se onbegryplike grootheid (Smit 1988:187; Wendel 1968:128) $)^{29}$.

Juis hierdie ontdekking om voor ' $\mathrm{n}$ lewende God te staan, is ' $\mathrm{n}$ antwoord op die Woord wat God reeds gespreek het. Deur die werking van die Heilige Gees het God van sy kant af die stilte verbreek. Hier waarheid word teologies geformuleer in die leerstuk van die openbaring en veral in die leerstuk van die persoonlike uitverkiesing (Berkouwer 1955:113) ${ }^{30}$. In die uitverkiesing gaan dit veral oor God se vryheid van ewigheid af. Hierdie vryheid is egter geen willekeurige vryheid nie, maar God wat, vreemd genoeg en onlogies, in vryheid sondaars kies en begenadig. Die evangelie gaan oor hierdie God se 'anders kies' as wat ons as mense kies. Calvyn se

Spiritus Sancti" word dikwels in verband gebring met die "verligting van die verstand'. Sonder die getuienis van die Heilige Gees kan die leer van die evangelie nie verstaan word nie.

29 Barth se stelling: "The Biblical presupposition that man has to do with the living God is through and through the vital nerve of Calvin's instruction on the Christian religion" (Smit 1988:187). "Gott und der Mensch müssen vor allem wieder ihre wahre Stellung einnehmen. Das ist der Grundgedanke, der Calvins gesamte Theologie beherrscht ..." (Wendel F W 1968 Calvin Ursprung und Entwicklung seiner Theologie. Neukircher Verlag, 128).

30 Die vraag oor die uitverkiesing was in die tyd van die Reformasie in die middelpunt van belangstelling (Berkouwer, G C 1955. De Verkiezing Gods in: Dogamtische Studien. J H Kok N. V. Kampen, 113). Ons sou kon vra hoe kom ons in ' $n$ pneumatologiese benadering by die leerstuk van die uitverkiesing uit? Interessant is dat Calvyn in boek III die Christelike vryheid, III, 19 behandel as voorspel tot die gebedsdeel: Inst. III, 20. Direk daarna behandel hy die verkiesingsleer in Inst. III, 21-24. 
Godsbeeld word gevorm deur die Skrif ${ }^{31}$. God se vryheid, word in sy volle omvang geopenbaar in die Woord; veral as sy vryheid tot geregtigheid en genade soos finaal geopenbaar in die koms, sterwe en opstanding van sy Seun Jesus Christus. Dat God Homself juis so openbaar, leer die Heilige Gees ons, is ons as mense se diepste troos $^{32}$.

Die leerstuk van die uitverkiesing het om verskeie redes problematies geword. Verloor die blye boodskap van die evangelie nie vanuit die verkiesing van God sy egte blydskap nie? Plaas die verkiesingsleer nie ' $n$ demper op die blydskap nie? Die vraag wat ons maar altyd vra is, hoe kan ons seker wees dat die evangelie werklik vir ons geld, moet ons nie eers langs 'n moeilike omweg of metode of ervaring sekerheid kry nie? Dis baie belangrik dat die verkiesing nie rasionalisties verstaan word, as daad vanuit die ewigheid, wat los staan van God se historiese verlossingsdaad in Jesus Christus nie (Berkouwer 1955:159) ${ }^{33}$. Ons is uitverkies 'in

31 Vanuit ' $\mathrm{n}$ Arminiaanse gesigspunt word Calviniste beskuldig van ' $\mathrm{n}$ oorbeklemtoning van God se mag ten koste van sy liefde (Walls, L W en Dongell, J R 2004. Why am I not a Calvinist. Intervarsity Press Illinois). Daarteenoor wys Berkouwer (1955:56 v) daarop: "Voor Calvijn heeft de vrijheid Gods niets te doen met een willekeurig in alle richtingen kunnen gaan of nu zo, en dan weer anders willen, omdat hij weet, dat de goedheid Gods onlosmakelijk met zijn macht verbonden is". Calvyn stel as volg: "Want God se goedertierenheid is op so " $\mathrm{n}$ wyse met sy Goddelikheid vervleg dat Hy noodwendig God sowel as goed is" (Inst. II, 3, 5:414).

32 Vir Calvyn is " $n$ naspeur van die verkiesing sonder die openbaring in Christus soos ' $n$ dodelike afgrond. Calvyn wys voortdurend op Christus, dan nie as teenwig teenoor die verborgenheid van die verkiesing nie, maar as spieël van die verkiesing. "As ons God se vaderlike sagmoedigheid en genadige gemoed soek, moet ons ten eerste ons oë na Christus wend in wie alleen die Vader se Gees rus". En verder: "Christus is dus die spieël waarin ons ons uitverkiesing behoort te aanskou en waarin ons dit ook sonder misleiding mag doen" (Inst 3.24.5 1218 - 1219).

33 Belangrik is dat Christus nie blote openbaring is van ' $n$ ewige uitverkiesing los van sy heilshistoriese versoeningswerk nie. Dat die geskiedenis tussen die wande van die verkiesingsleer sou verdwyn (Berkouwer 1955:159). Paradoksaal gestel, versoen God Hom omdat Hy ons tevore reeds liefgehad het; Calvyn erken die beslissende betekenis van die historiese heilsgebeure: "en die woord versoening dra groot gewig, want sedert die tyd waarop God ons op " $n$ onuitspreeklike wyse liefgehad het, was Hy terselfdertyd ook toornig op ons, totdat Hy in Christus versoen is" (Inst 2.17.2:689). Hierdie 
Christus'. Die Bybel skilder ons menslike verhaal as 'n verhaal van vyandskap, weg van God $\mathrm{af}^{34}$. Die evangelie is juis dat Jesus Christus die groot uitverkorene is. Deur sy gehoorsaamheid tot in die dood aan die kruis, voltrek God se geregtigheid oor ons ongehoorsaamheid en tegelyk is Hy ons genadig. God betaal in Christus die duurste prys, sodat die mens waarlik vry kan wees. Dat hierdie waarheid vir eens en altyd geld, word bevestig deur sy opstanding uit die dood. Deur die werking van die Heilige Gees skenk God die geloof wat hierdie nuwe vryheid persoonlik toe-eien. Ons kan hier praat van die geheim van die ervaring van ' $n$ persoonlike uitverkiesing wat al ons denke en berekeninge te bowe gaan (Lüthi 1952:267-8) . $^{35}$.

punt is belangrik want ' $\mathrm{n}$ abstrakte geïsoleerde besluit impliseer onmiddellik ' $\mathrm{n}$ verkiesingsdeterminisme. In die gereformeerde verkiesingsleer kan daar wel ' $n$ neiging tot abstraksie aangetoon word. Ons verwys hier na Barth se kritiek.

34 Die probleem is dat sonde te veel moralisties verstaan word; sonde handel oor ' $n$ geneigdheid by die mens weg van God af. Nie net die mens se dade is aangetas nie; maar sy wil. As ons sonde moralisties verstaan kom ons by beskrywings soos dat die mens 'sleg' is. Hierteenoor word dan gestel dat ' $\mathrm{n}$ mens wel goed is geskape met ' $n$ vrye wil. So word oor die heil in terme van ' $n$ sinergisme dink. Hierdie tipe denke laat nie werklik ruimte vir die boodskap van God se vrye genade soos dit ook in die uitverkiesing beklemtoon word nie.

35 Thomas kom tot 'n persoonlike geloofsbelydenis: "'Mijn Heer en mijn God!' Christus is voor hem, Thomas, Heer en God. Zoo kan de eeuwigheid liefhebben, zoo, dat zij de gansche volheid van haar barmhartigheid aan één bepaald, afzonderlijk mensch overdadig-verkwistend kan geven. De apostel Thomas ziet zich hier gesteld voor dit geheim der persoonlijke verkiezing. Elf discipelen zijn zij nog met elkander. De andere tien hebben acht dagen geleden den Opgestane gezien, alleen hij, Thomas, heeft Hem niet gezien, want hij was niet aanwezig. En nu ontmoet de Opgestane hen weer, en dit keer houdt Hij zich alleen en juist met Thomas bezig. Alsof de anderen heelemaal niet aanwezig zijn, richt de Opgestane zich enkel en alleen tot Thomas. En hem alleen pikt hij uit al de anderen uit, en spreekt hem alleen aan. Juist ter wille van dien eenen Thomas heeft zich de hemel hier opengedaan en zich moeite gegeven en is de Heer, aan wien alle macht in hemel en op aarde gegeven is, neergedaald om dezen eenen te ontmoeten en om met hem te spreken. Dat is het geheim der persoonlijke verkiezing. ... Voor het vierduizendste deel van dit geheim valt de tweeling Thomas op de knieën en roept uit: "mijn Heer en mijn God" (Lüthi, W. Het Evangelie van Johannes in die wereld van heden. Vert. W Volger. Franeker: T Wever. 267-8). 
In Christus uitverkies is die evangelie. Hierdie 'in Christus wees' kan met mistieke begrippe beskryf word, maar dit is ver van die mistiek verwyder (Kolfhaus 1939:126) ${ }^{36}$. In die pneumatologie staan Christus sentraal. Die werk van die Heilige Gees is om deur die gawe van die geloof ons met die gawes wat Christus ons skenk te verbind. Hierin lê die klem van die Calvinistiese pneumatologie (Calvyn 1981:19) ${ }^{37}$. Calvyn beskou geloof nie alleen as vertroue nie, maar ook as sekere kennis (Inst. III, 2, 2:710) ${ }^{38}$. Daar is vir die geloof ' $n$ wesenlike 'teenoorstaande'. Hierdie 'teenoorstaande' waarop die geloof gerig is, is die evangelie van Jesus Christus en sy heilsdaad vir ons (Inst. III, 2, 29:747) ${ }^{39}$. Hierdie 'teenoorstaande' is nie ' $n$ blote leer of ' $n$ boodskap nie, maar handel om ' $n$ persoon en sy werk. Die gelowige tree daarom in ' $n$ verhouding tot die Persoon

36 Kolfhaus wys in sy werk 'Christusgemeinschaft bei Johannes Calvin' op die feit dat uitdrukkings wat by die mistici voorkom nie vreemd is aan Calvyn nie. Calvyn beklemtoon ook die werk van die Gees. Hy beklemtoon egter die 'Heilige Gees' as Gees van Christus. Dit wat as grondtrek by die mistiek na vore kom as "eine Unmittelbarkeit zu Gott" is by Calvyn afwesig (Kolfhaus, W 1939. Christusgemeinschaft bei Johannes Calvin: Beiträge zur Geschichte und Lehre der reformierten Kirche. Dritter band. Neukirchen, 126).

37 Die Geneefse Kategismus, vraag 92, oor die geloof in die Heilige Gees: "Dit het groter duidelikheid nodig. Ek begryp dit so dat die Gees van God, terwyl Hy in ons harte woon, dit so bewerk dat ons die krag van Christus ervaar, want dit geskied deur die verligting van die Heilige Gees dat ons ' $n$ begrip vorm van die weldade van Christus. Deur die oorreding van die Heilige Gees gebeur dit dat die seëninge op ons harte afgedruk word. Kortom, die Heilige Gees alleen gee in ons daaraan ' $n$ plek. Hy laat ons weergebore word en veroorsaak dat ons nuwe skepsele word. daarom ontvang ons al die gawes wat in Christus vir ons gebring word, deur die krag van die Heilige Gees" (Calvyn J. 1981. Calvyn se Kategismus. vert. Simpson, H W. Potchefstroom: Teologiese Publikasies, 19).

38 "Geloof is nie in onkunde geleë nie maar in kennis; en dit nie alleen in die kennis oor God nie maar ook in die kennis van die wil van God.' Hy brei verder uit oor die inhoud van hierdie kennis. 'Ons verkry dit tewens omdat ons weet dat God ons genadige Vader is omdat deur Christus versoening gedoen is wanneer ons weet dat Christus waarlik tot geregtigheid, heiligmaking en die lewe aan ons gegee is. Ek herhaal: deur hierdie kennis, en nie deur die onderwerping van ons gevoelens nie, kan ons tot die koninkryk van die hemel toetree" (Inst. III, 2, 2:710) .

39 "Daar is immers niks wat die geloof kan bevestig anders as net die vrye boodskap waarmee God die wêreld met Homself versoen nie" (Inst. III, 2, 29:747). 
waarvan die evangelie getuig. In hierdie verhouding is van deurslaggewende belang die hoor van God se Woord, asook die gelowige aanvaarding daarvan. Die mistieke begrippe wat dus by Calvyn voorkom het ' $n$ heel ander inhoud en draagwydte. Dit staan nooit los van die Woord, die gawe van die geloof en die werk van die Heilige Gees nie. Die ervaring waarvan Calvyn praat is van 'n ander oorsprong: die hoor van die Woord van God (Inst. III, 2, 6:715) . $^{40}$. Die wysheid van die Woord oortref al ons menslike wysheid ${ }^{41}$. Daarom gaan ' $n$ Pneumatologiese benadering hand aan hand met ' $n$ herwaardering van die Skrif as God se lewende herskeppende Woord. Rossouw (1963:246) vat dit treffend saam:

"Die reformatoriese Skrifbeskouing was self ' $\mathrm{n}$ moment in die reformatoriese herontdekking van die Bybelse religie, ' $n$ herontdekking wat plaasgevind het in die omgang en interpretasie van die Skrif self. In die herontdekking van die Bybelse religie is die gesag van die Skrif tegelykertyd herontdek as die konkrete, heilsgebeurlike gesag van Gods lewende Woord. Waar die Woord van God in die geloof verneem word, daar gebeur die heil wat eenmaal eens-vir-altyd in die geskiedenis van Israel en Jesus van Nasaret geopenbaar is as heil van Gods komende Koninkryk. As die getuigende oorlewering van hierdie geskiedenis is die Skrif self die Woord wat God hede spreek in die konkrete bestaan van die sondaar. Die Skrif verkondig dus nie net dat die geskiedenis van Israel en Jesus van Nasaret die eenmalige Openbaring van Gods heilshandelinge met die sondaar op sy weg na die verwerkliking van sy eskatologiese heerskappy nie, maar die Skrif het self ' $n$ funksie op hierdie weg en in die verwerkliking. Deur die

40 "Eers moet ons gewaarsku wees dat die geloof vir ewig in ' $n$ verhouding met die Woord staan en dat dit net so min van die Woord losgeskeur kan word as wat die strale van die son, wat die bron daarvan is, losgemaak kan word" (Inst. III, 2, 6:715).

41 "Wie sein Freund und Lehrer M. Butzer betonte Calvin im Gegensatz zu dem 'inneren Wort' der Mystiker und Schwärmer die entscheidende Bedeutung der Heiligen Schrift für unser Glauben und Leben. Statt herabzusteigen in die eigenen Seelentiefen, "muss der Glaube seine Wurzeln tief in Gottes Wort hineingesenkt haben" Kolfhaus (1939:128) verwys na C O. 48, 317. 
Skrif as sy lewende Woord oefen God sy heerskappy tans reeds uit daarin dat Hy geloof oproep en so die mens stel in ' $n$ lewende gemeenskap met Homself, " $n$ gemeenskap van kennis en vertroue, van gebed en liefde, van diens en verwagting. As die evangelie van Gods verkiesende liefde en van sy vrye genade is die Skrif die "septer van Gods Koninkryk". God heers deur sy Woord. Gods heerskappy beteken heil vir die sondaar".

Die vereniging met Christus geskied deur die geloof alleen en nie menslike tegnieke en metodes nie ${ }^{42}$. Hierdie gelowig wees is geen grootheid in homself as ' $\mathrm{n}$ ingebore gelowig wees, los van die Heilige Gees se voortdurende troos en versekering nie ${ }^{43}$. Hier bly die mens altyd hoorder wat hoort by die Woord; die Woord van vergifnis van sondes in Jesus Christus; en die Woord van die belofte van ' $\mathrm{n}$ nuwe toekoms en die geloof as die aanvaarding van hierdie versekering en beloftes van $\mathrm{God}^{44}$. Belangrik is dat die heilstoeeiening vir die hervormers nie ' $n$ subjektiewe toe-eiening is van iets wat objektief vasstaan nie.

"Die geloof waarin die belofte verneem en vervul word, is vir die Reformatore geen beslissing van menslike vryheid téénoor " $n$ objektiewe grootheid wat aan die mens voorgehou word nie. Dit is veeleer die opgeneem

42 "Die vereniging met Christus geskied alleen deur die geloof; dit beteken die mens kan in eie krag niks daartoe bydrae nie. Die beweging wat tot vereniging met Christus lei begin nie by die mens nie; Christus begin die beweging deur die werking van die Heilige Gees. Soos in die nagmaalsleer maak die Heilige Gees alleen hierdie eenheid met Christus vir ons moontlik" (Inst. III, 1, 1).

43 Dat die uitverkiesing nie aanleiding gee tot selfingenomenheid nie: “... want daar is niemand te vind wat nie nog ver daarvan af weg is nie" (Inst. III, 6, 5:881). "Maar as ons in Hom uitverkies is, sal ons in ons geen sekerheid oor ons uitverkiesing vind nie en selfs ook nie eens in God die Vader as ons Hom alleen en sonder die Seun voorstel nie. Christus is dus die spieël waarin ons ons uitverkiesing behoort te aanskou en waarin ons dit ook sonder misleiding mag doen" (Inst. III, 24, 5:1219).

44 "Want hoewel die geloof in ons uitverkiesing ons besiel om God aan te roep, sou dit nogtans voorbarig wees om, wanneer ons gebede bedink, die uitverkiesing aan God op te dring of onder hierdie voorwaarde "n ooreenkoms met Hom te bereik: "O Here, as ek uitverkies is, verhoor dan". Dit is trouens sy wil dat ons met sy beloftes tevrede moet wees" (Inst. III, 24, 5:1219-1220). 
word van die mens deur die Woord in die volheid van Gods beslissing oor en vir die sondaar, d.w.s. in die volheid van Gods raadsbesluite soos dit heilshistories geopenbaar is in die werklikheid van die Immanuel" (Rossouw 1963:225).

Die vervulling word nie afhanklik gestel van die mens en sy samewerking nie. Dit word enkel en alleen moontlik gemaak deur God se toewending, deur sy lewende Woord. Tog is ook hier geen sprake van ' $n$ outomatisme nie, want ook in sy spreke bly God die Heer. Dit beteken God is Gees. Daarom moet ons verder leer: "In die vervullingsdimensie van die Skrifgesag gaan dit om die verbondenheid van Woord en Gees. Christus is vir die geloof werklik teenwoordig in sy Woord - maar dan nie anders as deur sy Gees nie"(Rossouw 1963:226) ${ }^{45}$. In Calvyn se uitsprake is daar altyd twee lyne. Daar is uitsprake wat die genoegsaamheid van die Skrif beklemtoon en daar is uitsprake wat die verligting deur die Heilige Gees beklemtoon (Rossouw 1963:238) ${ }^{46}$. Die geloof is dus veral ' $n$ gawe van die Heilige Gees.

Ons kom so in " $\mathrm{n}$ verhouding tot God as ons Vader in Christus deur die werking van die Heilige Gees. Calvyn voeg in sy 1559 uitgawe, as deel van die uitleg van die woorde 'Ons Vader', die volgende by:

"Omdat die beperkinge van ons hart die onmeetlikheid van so " $\mathrm{n}$ goedgunstigheid nie kan bevat nie, is Christus nie alleen vir ons die pand en waarborg van ons aanneming nie, maar Hy gee ook die Gees as getuie van dieselfde aanneming aan ons, deur wie ons met ' $n$

45 "Dat die Reformatore dit weer ontdek het, kan die dogma-historiese novum van die hervorming genoem word. Luther en Calvyn het vir die eerste maal in die geskiedenis van die kerk ' $n$ konsekwent trinitariese teologie ingelui" (Rossouw 1963:226).

46 “God het 'n 'duplicum ... docendi modum'. Daarom bestaan die leerwyse waarvan die profete spreek nie net in die uiterlike spraak nie, maar ook in die geheime werksaamheid van die Gees in die hart van die mens" (op cit 238). Rossouw (1963:238) haal aan $C R$ 47, 149: '... non in externa tantum voce sita est, sed in arcana etiam spiritus sancti operatione. In summa, hoc Dei magisterium est interior cordis illuminatio'. Calvyn se siening van die Skrif as lewende Woord van God moet gesien word teen die agtergrond van die getuienis van die Heilige Gees. 
vrymoedige en helderklinkende stem kan uitroep: 'Abba, Vader!' (Rom. 8:15; Gal. 4:6) So dikwels as wat enige vertwyfeling dus vir ons ' $\mathrm{n}$ struikelblok is, moet ons onthou om Hom te vra om ons vreesagtigheid weg te neem en ' $\mathrm{n}$ gees van grootmoedigheid as leidsman aan ons te gee om vrymoedig te bid" (Inst. III, 20, 37, 1136).

Sonder die roepstem van God in Christus sou ons gebed stil word; " $n$ hopelose roep in die niks. 'In Christus' is God nie ' $n$ verre onbetrokke geheimenis nie maar ons wagtende Vader, Abba Vader! Die Heilige Gees skep daarmee die vryheid om te bid (Scholl $1968: 154)^{47}$. Juis in sy nadenke oor die werk van die Heilige Gees, kom Calvyn op die spoor van die wonder van gebed en vind sy teologie juis in gebed ' $n$ duidelike scopus (Locher 1964:14) ${ }^{48}$. Calvyn praat van die grootste geskenk van die Heilige Gees - gebed. Ons verwys na Calvyn se beskrywing in Institusie III, 20, 2:

"Deur die weldaad van gebed bereik ons dit dus om na daardie rykdomme deur te gaan wat by die hemelse Vader vir ons weggebêre is. Daar is tewens ' $n$ sekere verkeer van mense met God waardeur gelowiges wat tot die heiligdom van die hemel toegetree het, Hom persoonlik in verband met sy beloftes kan aanroep sodat, as die nood dit vereis, hulle self kan ervaar dat dit wat hulle geglo het, nie sonder grond was nie, hoewel Hy dit toe slegs in woorde aan hulle meegedeel het. Gevolglik kan ons sien dat geen belofte aan ons voorgehou word om van die Here te verwag sonder dat ons ook gebied word om dit in ons gebede van Hom te vra nie. Dit is daarom waar dat ons met ons gebede die skatte uitdelf wat die evangelie

47 Gebed onder leiding van die Heilige Gees vorm ' $\mathrm{n}$ raakpunt tussen rasionaliteit en ervaring in Calvyn se teologie. Ons sien dit veral in Calvyn se uitleg van die Ons Vader. Calvyn doen moeite met die uitleg van die 'Ons Vader'. Daarvan getuig die veranderinge wat in elke uitgawe van die Institusie voorkom. Veral die eerste drie bedes kry die meeste aandag. Die 'Ons Vader' is die Bybelteks wat Calvyn die meeste uitlê. Moontlike getuienis van die geheim van die 'Ons Vader', 'n geheim wat selfs Calvyn nie volledig begryp. Scholl (1968:154) verwys na die verskillende uitlegte sedert 1536 tot en met 1561.

48 "So hält Calvin den Personal charakter des redenden Gottes und den des angeredeten Menschen bis zuletzt durch" (Locher 1964:14). 
van die Here vir ons aangedui het en wat ons geloof al aanskou het".

Reeds in die Institusie uitgawe van 1539, onder invloed van sy studies oor die Romeine brief, beantwoord Calvyn die vraag na die 'hoe' van gebed met ' $n$ verwysing na Romeine 8 . Ware gebed is ' $n$ gawe van die Gees. Onder die werking van die Gees staan die mens egter nie soos ' $n$ stok in ' $n$ blok nie, maar as mens; ook nie as " $n$ gevange slaaf nie, maar in vryheid ${ }^{49}$. Menslike inisiatief word dus juis deur die Gees gevra. Hierdie werking van die Heilige Gees blyk die eintlike geheim en sin van Calvyn se pneumatologie te wees; daarmee saam ook die eintlike wonder van gebed as 'n vrye deelname van die mens. In gebed kan die mens homself wees soos voor geen ander nie; ervaar dat hy aanvaar word nes hy is; ervaar dat sy unieke verhaal ook vir God belangrik is en deur Hom gehoor word.

Die vryheid wat die Heilige Gees skep is geen willekeurige vryheid nie. Gebed bring ons binne die ruimte van die wil van God, daarom gaan gebed ook gepaard met dank. Die woord 'dank' hou verband met die woord 'gedenk' ${ }^{50}$ 'Dank' is ' $\mathrm{n}$ daad van erkentenis teenoor God. Gebed as 'dank' bring die teologiese kenproblematiek na vore. Dit onderstreep die sentrale gedagte dat eers hy wat God se genade leer ken, waarlik bid ${ }^{51}$. Die 'gedagte', die 'bedink van' God se wese, sy goedheid spoor aan tot gebed en 'dank" ${ }^{52}$. Tog bly die subjek van hierdie erkentenis in laaste instansie God wat die mens voorstel aan sy almag en goedheid (Scholl 1968:40v) ${ }^{53}$. 'Dank' word

49 “... ek sê dit eerder sodat ons 'n afkeer in ons luiheid en traagheid kan ontwikkel en sulke bystand van die Gees kan najaag” (Inst. III, 20, 5, 1084).

50 Van die min gebede van Calvyn waarin meer 'dank' (ook meer aanbidding) as gebedsversoeke voorkom is sy gebed na die nagmaal. Die Nagmaal wat juis handel oor 'gedenk' (Quervain, de A. 1948. Das Gebet: Ein Kapitel der Christlichen Lehre. Zürich: Evangelischer Verlag).

51 “... unless God both gave him wisdom, and opened up for him a way where no way is. It becomes us, after his example, to do the same thing; so that distrusting ourselves when counsel fails us, and the malice and wickedness of our enemies prevail, we may betake ourselves speedily to God, in whose hands are the issues of death, as we shall see afterwards" (Com. Ps 5:8).

52 Sien Calvyn se preek n.a.v. 2 Sam. 7:19.

53 Die opbou van die Geneefse kategismus van 1542 onderstreep hierdie punt. Dank laat die bidder uitkom by die wyer ruimte van God en sy genade en 
so die ruimte waarbinne die teologiese nadenke voltrek word. Terwyl gebed as 'bede' beperk bly tot die gebedshoofstuk van die Institusie, vorm 'dank' die horison waarbinne die hele teologiese uiteensetting van die Institusie plaasvind. Volgens Institusie I, 17, 7 bly 'dank' nie by woorde nie, maar moet dit aanleiding gee tot dade. Hierin is die opbou van die Heidelbergse Kategismus voorberei, waarin gebed verstaan word as die vernaamste deel van ons 'dankbaarheid'. Dat 'dank' aanleiding gee tot die etiek blyk duidelik uit Institusie deel III. Dankbaarheid eindig nie met gebed nie, dit raak die hele lewe. Lof en dank is nie die resultaat van menslike begeestering nie, maar is slegs moontlik onder leiding van die Heilige Gees. Gebed, menslike daad van 'bede' en 'dank', staan nie los van die werk van God drie-enig nie (Scholl 1968:47). Gebed word so die raakpunt tussen die objektiewe en subjektiewe kant van die geloof.

Die vryheid wat die Heilige Gees skep is ' $n$ vryheid tot verantwoording en verantwoordelikheid. Die groot gevaar in die Calvinisme is ' $\mathrm{n}$ oorbeklemtoning van die rasionele ten koste van die ervaringsmatige. Tekenend hiervan is dat gebed ' $n$ verwaarloosde tema in die Protestantse teologie blyk te wees (Scholl 1968:9; Berkhof 1979:495) $)^{54}$. Ons hoor van en glo selfs die teologie van

stoot uiteindelik in die 4de deel deur in die ruimte van godsdiens. Dank in gebed moet oorloop in die lewe van ' $n$ Christen. Die uitbreiding van die dankgebed geskied uiteindelik in die ganse teologiese ruimte van die 4 dele van die Institusie.

54 Teenoor die aanvang van die gereformeerde Christendom waar Luther en Calvyn uitgestaan het as bidders, is gebed ' $\mathrm{n}$ afgeskeepte tema in die Protestantse teologie. Scholl verwys na O, Weber, Grundlagen der Dogmatik, 2 bande, Neukirchen 1955; in die geheel van 2000 bladsye neem verwysings na gebed 1 bladsy in beslag. In Heppe/Bizer, se Die Dogmatik der evangelischreformierten Kirche, Neukirchen, 1958, 2de uitgawe word geen plek gewy aan die locus oratione nie. Tot dusver ontbreek ' $n$ dogmengeskiedenis van die christelike (veral protestantse) gebed (Scholl 1968:9). Berkhof se stelling sluit hierby aan: "In the study of the faith prayer is a neglected theme...[W]here prayer is neglected, it could be a sign (though this is not absolutely certain) that either man's freedom or God's power is underrated; the first is the case in predestinarian-marked Reformed Scholasticism, the second in 19th century modernism and 20th-century Existentialism. Prayer becomes an integral theme only in a study of the faith which follows the structure of the covenant" (Berkhof, H 1979 Christian faith, tr. S Woudstra, WB Eerdmans: Grand Rapids, 495. Sien ook Doekes, L 1979. 'Het gebed in de gereformeerde 
genade, maar dis nie hoe ons leef nie! Hoeveel meer heel sou ons lewe gewees het as ons die goeie nuus van God se evangelie van genade werklik sou laat wortelskiet in ons lewe en emosies? Hier moet ons opnuut in die leerskool van die Heilige Gees kom staan. Die goeie nuus is dat ons in Christus waarlik vry is; vry van die oorheersing deur die sonde; maar ook vry om God te dien. Die Heilige Gees werk die vryheid om God se Woord te hoor én te gehoorsaam. Die Heilige Gees maak die mens verantwoordbaar en verantwoordelik. Verantwoordbaar teenoor God in die eerste plek; teenoor die naaste, maar ook die ganse skepping. Deur die verligtende werking van die Heilige Gees ontdek die mens dat hy/sy nie aan hom/haarself behoort nie. God kom eerste, voor alles, ook voor die mens. Die mens is geskep volgens die beeld van God. Calvyn sien die bedoeling van die ganse geskiedenis saamgevat in soli Deo gloria ${ }^{55}$. Die gelowige se lewe draai dus nie om eie verlossing nie; God is nie net ' $n$ middel tot ' $n$ doel, naamlik die verlossing van die mens nie; God verlos die mens juis van ' $n$ sondige selfgerigtheid. Die gelowige leef om God te eer; om aan God sy regmatige plek te gee. Hierdie beklemtoning kom ook duidelik na vore wanneer Calvyn die Christelike lewe saamvat onder die begrip selfverloëning (Inst. III, 7. 1:883). Calvyn beskou selfverloëning nie as ' $\mathrm{n}$ negatiewe saak nie, maar as ' $\mathrm{n}$ positiewe houding teenoor God en andere. Selfverloëning vind om een rede plaas: die Here se Naam word daardeur groot gemaak. My ganse lewe is voortaan positief daarop ingestel om God te behaag (Inst. III, 7, 2:884). Richard (1974:126) gebruik die term 'inner-worldly ascetism' om Calvyn se spiritualiteit te beskryf. "His ideal was not withdrawal from the world, but the conquest of the world for the glory of God"56.

Calvyn praat ook van ' $\mathrm{n}$ tweede werk van die Heilige Gees. Deur die werking van die Heilige Gees word Christus se amp ook

dogmatiek na Calvijn', in 'De Biddende Kerk, red Trimp, C. Groningen: De Vuurbaak).

55 "Dit is nou ' $n$ belangrike onderwerp - dat ons aan God gewy is en aan Hom toegesê is om hierna niks te dink, te sê, te beplan of te doen behalwe as dit tot sy heerlikheid strek nie" (Inst. III, 7, 1:883).

56 Richards, L J 1974. The Spirituality of John Calvin. Atlanta: John Knox Press, 126. 
die amp van die gelowige (Calvin 1961/1962:794) ${ }^{57}$. Deur die werking van die Heilige Gees, is elke gelowige ' $n$ lid van die liggaam van Christus, aan Hom verbonde, en deelnemend aan sy amp. In die Christologiese deel van die Institusie, II, 15, 2, omskryf Calvyn die betekenis van die profetiese amp as volg: "Hier moet ons weer daarop let dat Hy die salwing nie alleen vir homself ontvang het om sy leerfunksie te verrig nie, maar ook vir sy hele liggaam, sodat die krag van die Gees met die voortdurende verkondiging van die evangelie ooreenstem" (Inst II, 15, 2:650). So oefen Christus sy koninklike heerskappy ook uit om ons ontwil ${ }^{58}$. In die deelname aan Christus se koninklike amp, is die Christen self oorwinnaar oor die bose en die duiwel. Die behandeling van die priesterlike amp kom laaste aan die beurt. Hierdeur beklemtoon Calvyn die middelaarskap van Jesus Christus. Die unieke karakter wat dit aan die Christen se gebede verleen is die belangrike plek wat voorbidding inneem. "Das Beten Calvins mündet aus in ein Meer der Fürbitte, in ein Ringen um das Heil des leibes und der Seele von vielen"(Scholl 1968:240). Die reikwydte van voorbidding wys op die reikwydte van ware godsdiens by Calvyn ${ }^{59}$.

\section{TEN SLOTTE}

So spel God se genadige uitverkiesing in Christus, deur die werking van die Heilige Gees vryheid én verantwoordelikheid: vryheid van die ou self, maar tegelyk 'verantwoordbaarheid' teenoor God. Sin vind die mens eers binne hierdie ruimte wat die Heilige Gees skep.

57 “... nachdem Christus uns durch das innerliche Wirken des Geistes mit sich verbunden und in seinen Leib aufgenommen hat, macht er noch eine zweite Wirkung des Geistes offenbar, indem er uns reich macht an Geistesgaben ... dass das Streben nach Gerechtigkeit und Frömmigkeit kräftig in uns lebt, dass wir eifrig sind zum Gebet, dass der Gedanke ans ewige Leben uns aufwärts zieht, dass fließt, sage ich, aus dieser zweiten Gemeinschaft, indem Christus, um nicht müßig in uns zu wohnen. Die Kraft seines Geistes in deutlichen Gaben zeigt" (An Pietro Martire Vermigli in Straßburg, 8. August 1555. Calvin 1961/1962. Lebenswerk in seinen Briefen. Eine Auswahl von Briefen Calvins in deutscher Übersetzung von $\mathrm{R}$ Schwarz. 3Bde. Neukirchen,794).

58 Sien sy preek oor Deut, 17:14-18 in: Calvin J. 1864/1897, Ioannis Calvini opera quae supersunt omnia. ed. Baum, Cunitz \& reuss. 58 bde. Brunsvigae: Schwetschke et Filium, 462.

59 Kry ons hier ' $n$ ander beeld van Calvyn, Calvyn as teoloog van die gemeente? 
Op 'n narratiewe wyse gestel, hoe word my nietige verhaal deel van God se ewige verhaal? Die Heilige Gees maak my 'verantwoordbaar'. In die eerste plek teenoor God wat in Christus my Vader geword het. Sy liefde maak my verantwoordelik. Verantwoordelik teenoor my medemens wat ek nou sien as my naaste; verantwoordelik teenoor die ganse skepping. My lewensituasie sien ek nou as die plek en tyd waarin God my geplaas het en waarvoor ek verantwoordelikheid moet neem. So herstel die Heilige Gees my as beelddraer van God en word my verhaal uniek en onherhaalbaar.

\section{Literatuurverwysings}

Barth, K 1955. The Theology of John Calvin. Michigan: W B Eerdmans.

-, 1972. Protestant theology in the nineteenth century. London: SCM..

Berkouwer, G C 1955. De Verkiezing Gods in: Dogamtische Studien. Kampen: J H Kok N. V.

Calvin, J 1961/1962. Lebenswerk in seinen Briefen. Eine Auswahl von Briefen Calvins in deutscher Übersetzung von R, Schwarz. 3Bde. Neukirchen.

-, 1984/1991. Institusie van die Christelike godsdiens, vol I-IV. vert Simpson, H W. Potchefstroom: CJBF. Afgekort: Inst.

Doekes, L 1979. 'Het gebed in de gereformeerde dogmatiek na Calvijn', in 'De Biddende Kerk, (red) Trimp, C. Groningen: De Vuurbaak

Egan, H 1980. 'The Devout Christian of the future will... be a mystic': Mysticism and Karl Rahner's theology, in: Theology and discovery: Essays in honour of Karl Rahner, ed. W J Kelly. Milwaukee: Marquette Univ Press,

Häring, B 1975. Prayer: the integration of faith and life, 1. Fides: Indiana.

Jonker, W D 1985. 'Die verhouding tussen die Christelike geloof en mistiek', NGTT (1985), 409-420.

Kasper, W 1979. Theologie in einer Zeit des Umbruchs, Theologische Quartalschrift (1979), 159. München: Erich Wewel Verlag.

-, 1988. Die Wissenschaftspraxis der Theologie, in Handbuch der Fundamental-Theologie, 4. hg Walter Kern e a. Freiburg: Herder.

Klinger, E 1994. Das Absolute Geheimnis im Alltag entdecken: Zur spirituellen Theologie Karl Rahners, Würzburg: Echter Verlag.

Kolfhaus, W 1939. Christusgemeinschaft bei Johannes Calvin: Beitrage zur Geschichte und Lehre der reformierten Kirche. dritter band. Neukirchen.

König, A 2002, Ek glo die Bybel - ondanks al die vrae. Wellington: Lux Verbi.

Krusche, W 1957. Das wirken des Heiligen Geistes nach Calvin. Göttingen: Vandenhoeck \& Ruprecht.

Locher, G W 1964. Testimonium internum: Calvins lehre vom Heiligen Geist und das hermeneutische Problem, Theologische Studien, Heft 81. Zürich: EVZ Verlag. 
Lüthi, W 1952. Het Evangelie van Johannes in die wereld van heden. Vert. Deur W Volger. Franeker: T Wever.

McGrath, A E 1994. Spirituality In An Age Of Change Rediscovering the Spirit of the Reformers. Grand Rapids: Zondervan.

Molnar, P D 1985. "Can we know God directly". Rahner's solution from experience. Theological Studies 46(1985), 224-238.

Rahner, K 1967. Glaubst du an Gott? 112-127. München: Verlag Ars Sacra.

-, 1974. 'Reflections on Methodology in Theology,' in: Theological Investigations 11, tr. Bourke, D. London: Darton, Longman \& Todd.

-, 1976. Grundkurs des Glaubens. Freiburg: Herder.

-, 1979. 'Beten als Grundakt' in Rechenschaft des Glaubens, hg. von Lehman, K und Raffelt, A. Freiburg: Herder,

-, 1982. Im Gespräch, Bd. 1, hg. Imhof, P en Biallowons, H. München: Kösel.

-, 1983a. 'Rede des Ignatius von Loyola an einen Jesuiten von heute', in: Schriften zur Theologie XV, 373-408. Einsiedeln: Benziger Verlag.

-, 1983b. 'Hierarchie der Wahrheiten'. Schriften zur Theologie XV. Einsiedeln: Benziger Verlag,

Quervain, de A 1948. Das Gebet: Ein Kapitel der Christlichen Lehre. Zürich: Evangelischer Verlag.

Richards, L J 1974. The Spirituality of John Calvin. Atlanta: John Knox Press.

Rossouw, H W 1963. Klaarheid en interpretasie, Enkele probleemhistoriese gesigspunte in verband met die leer van die duidelikheid van die Skrif. Proefskrif. Amsterdam: Jacob van Kampen.

Schlink, E 1961. Der kommende Christus und die kirchliche Traditionen. Göttingen: Vandenhoeck \& Ruprecht.

Scholl, H 1968. Der Dienst des Gebetes nach J. Calvin, Zwingli Verlag: Zurich.

Seckler, M 1984. Das eine Ganze und die Theologie, in: Glaube in Prozess, hg. Klinger, E und Wittstadt, K, Herder: Freiburg.

Sheldrake, P 1998. Spirituality and Theology. Christian Living and the doctrine of God. Darton, Longman \& Todd: London.

Smit, D J 1979. Teologie as Antropologie?, ' $n$ kritiese beoordeling van die transendentaal-antropologiese teologie van Karl Rahner, ongepubliseerde proefskrif, Univ van Stellenbosch.

Sprenger, P 1960. Das Rätsel um die Bekehrung Calvins. Neukirchen: Neukircherer Verlag.

Tillich, P 1967. Perspectives on $19^{\text {th }}$ and $20^{\text {th }}$ Century Protestant Theology, London.

Walls, L W en Dongell, J R 2004. Why am I not a Calvinist. Illinois: Intervarsity Press. 
Wendel F W 1968. Calvin Ursprung und Entwicklung seiner Theologie. Neukirchen: Neukircher Verlag.

Wethmar, C J 1988, 'Godsleer en gebed' in die bundel: 'n Woord op sy tyd, in: Wethmar, C J en Vos, C J A (reds), NG kerkboekhandel. 